\title{
ЗМІНА РОЛІ ВЧИТЕЛЯ В НАВЧАЛЬНОМУ СЕРЕДОВИЩІ - ОДНЕ 3 ОСНОВНИХ ЗАВДАНЬ СУЧАСНОЇ МЕТОДИКИ НАВЧАННЯ ГЕОГРАФІЇ
}

Топузов О. М., Надтока О. Ф. Зміна ролі вчителя в навчальному середовищі - одне 3 основних завдань методики навчання географії.

У статті розглядається одне 3 актуальних питань сучасної методики навчання географії - переосмислення ролі вчителя в навчальному середовищі. Зазначається, що нині вчитель перестає бути ретранслятором знань, а стає для учнів порадником, консультантом та організатором процесу навчання. Ці підходи підкріплюються комплексом методичних рекомендацій, що стосуються організаційно-діяльнісного, дидактичного та методичного аспектів цієї проблематики.

Ключові слова: навчальне середовище, методика навчання географії, якість географічної освіти, курикулум, технологізація процесу навчання.

Топузов О. М., Надтока О.Ф. Смена роли учителя в учебной среде - одно из основных заданий методики обучения географии.

В статье рассматривается один из актуальных вопросов современной методики обучения географии - переосмысление роли учителя в учебной среде. Подчёркивается, что сегодня учитель перестаёт быть ретранслятором знаний и становится для учеников советчиком, консультантом и организатором процесса обучения. Данные подходы укрепляются комплексом методических рекомендаций, касающихся организационнодеятельностного, дидактического и методического аспектов этой проблематики.

Ключевые слова: учебная среда, методика обучения географии, качество географического образования, куррикулум, технологизация процесса обучения.

Topuzov O. M., Nadtoka O. F. Changing the role of a teacher in the learning environment as one of the main tasks of geography teaching methods.

One of the most urgent issues for modern methods in teaching geography as redefining the role of a teacher in the learning environment is considered in the article. It is emphasized that today the teacher ceases to be a repeater of knowledge for his students and becomes an advisor, consultant and facilitator of the learning process. These approaches are strengthened by a set of guidelines relating to organizationally active, didactic and methodological aspects of this problem.

Key words: learning environment, methods of teaching geography, the quality of geographical education, curriculum, technification of learning process.

У часи глобалізації та реформування освітньої системи України загальноосвітня школа $є$ важливим джерелом оновлення суспільства. Вона поступово стає однією із інституцій забезпечення стабільного розвитку країни. Від фундаментальності та універсальності іiі філософських i методичних засад залежить якість результатів перетворення суспільного устрою та формування нової моделі соціальних відносин в Україні. На сучасному етапі одним із найважливіших напрямків реформування освітньої галузі є модернізація змісту загальної середньої освіти, яка б транслювала комплекс дидактично опрацьованих наукових знань, що у своїй сукупності мають відображати стрімкий прогрес науки й техніки; зміни в соціальних відносинах і суспільній свідомості; 
нові явища в галузях освіти, науки та культури. У багатьох країнах світу, передовсім у європейських, створені національні комісії з перегляду змісту освіти. Об'єктами їхньої діяльності $є$ аналіз шкільної освіти, як у загальному контексті, так і в плані розгляду ролі учасників навчального процесу. Тому актуальним у цьому плані є дослідження ролі вчителя в сучасних умовах інформаційного та глобалізованого світу.

Закономірне підвищення вимог до рівня і якості освіти спонукає до пошуку шляхів удосконалення навчально-виховного процесу в загальноосвітній школі [2].

3 огляду на викладене, географічна освіта характеризується низкою особливостей i перспектив для розвитку. Географія як наука за своїм змістом $\epsilon$ комплексною та інтегративною, завдяки їй відбувається перетворення знань про природу і людство в єдину наукову географічну картину світу.

У результаті тестувань учнів загальноосвітніх навчальних закладів та проведених бесід з учителями, здійсненого педагогічного спостереження, нами вивчено суспільнопедагогічну думку стосовно важливих змін у методиці навчання географії, спрямованих на реалізацію особистісно зорієнтованого навчання на основі використання компетентнісного, проблемного, діяльнісного, краєзнавчого підходів й оновлення понятійного апарату географічних курсів. Вельми актуальним у цьому плані $\epsilon$ зміна ролі вчителя на тлі вдосконалення шкільної освіти.

У переліку мотивів пізнання, які грунтуються на процесах навчання і самоосвіти, серед учнів основної школи домінують- світоглядні, що спираються на прагнення розширити життєвий світогляд, тобто сформувати певну географічну картину світу. На основі цього визначено психолого-педагогічні основи формування географічної картини світу в учнів основної школи та розроблені основні концептуальні засади щодо створення підручників нового покоління. Але ще недостатньо повно сформовані положення, які б характеризували роль учителя географії в сучасних умовах навчального середовища, яке стрімко змінюється під впливом інформаційного суспільства [7].

Можемо констатувати, що нині, орієнтація навчального процесу тільки на сприйняття певної сукупності знань, задекларованих навчальною програмою, тим більше стиснутої в часі, обмеженої у плані реалізації практичного складника, не відповідає ані умовам, що змінилися, ані вимогам суспільства. Тому основні характеристики процесу навчання географії, його зміст і структура, потребують нині серйозних змін, пов'язаних із змінами в самому навчальному середовищі, де у зв'язку з еволюціонуванням інформаційних потоків учитель перестає виконувати роль ретранслятора знань і основного джерела інформації в навчальному середовищі. 3 урахуванням вищезазначене, відбувається комплекс змін у методиці навчання географії- відбуваються парадигмальні зрушення в бік особистісно зорієнтованого навчання, змінюється змістове наповнення підручників, відчуваються вияви технологізації навчання, навчальний процес стає ареною застосування методик активного навчання, в тому числі, має містити елементи компетентнісно зорієнтованого, проектного i проблемного навчання.

Проблематика еволюціонування методичних засад навчальних предметів та зміна ролі вчителя в сучасній освіті є доволі спорідненими та неодноразово ставали об'єктами педагогічних досліджень. Філософські та методологічні питання, що стосуються ролі вчителя в навчальному процесі сучасної системи освіти України, розробляли В. Андрущенко. I. Зязюн, В. Кремень, В. Луговий, О. Пометун. О. Савченко. Зокрема В. Кремень указує на філософський аспект порушеної проблематики, зазначаючи, що нині формуються нові інтелектуальні стратегії, у яких відображаються цілісність і глобальний 
взаємозв?язок дій людей у практиці нашої цивілізації. Він зазначає, що змінюється статус індивідуального, яке не $\epsilon$ одиничним, а єдиним, здатним утілювати весь світ, сконцентрований в межах особистості [6].

Питання, що стосуються ролі вчителя у процесі навчання географії розглядали у своїх роботах О. Брацлавська, С. Кобернік, В. Корнєєв, М. Криловець, О. Надтока, О. Топузов та ін. Зокрема О. Топузов зазначає, що для оцінки ролі вчителя в навчальному процесі перспективним є застосування методичної прогностики. Вона забезпечує реалізацію низки важливих сторін педагогіки:

- дослідження закономірностей, обгрунтування принципів, розроблення методів прогнозування в галузі навчання;

- передбачення змін у суспільних та особистісних запитах до процесів освіти й навчання в майбутньому, вивчення чинників, що зумовлюють ці зміни, обгрунтування на цій основі конкретних вимог до результатів навчання й освіти в найближчій та віддаленій перспективі;

- передбачення цілей, напрямів та шляхів випереджального розвитку методики як науки;

- прогнозування тенденцій та пріоритетних напрямів розвитку системи освіти, пов'язаних 3 ним трансформаційних змін у процесі навчання (як системних, так i в компонентах зазначеного процесу);

- передбачення цілей і напрямів модернізаційних змін в управлінні процесом навчання, навчально-методичній роботі в загальноосвітньому навчальному закладі;

- прогнозування параметрів освітнього простору й освітнього середовища навчального закладу з урахуванням нових суспільних та особистісних потреб, майбутніх цілей та завдань освітньої діяльності;

- пошук й передбачення нових освітніх технологій тощо;

- передбачення конкретних вимог до змісту й результатів освітньої діяльності вчителя, навчальної діяльності учня, які зумовлюватимуть нові суспільні, економічні та особистісні запити до освіти в майбутньому [8].

Meта статmi - рокрити роль учителя у процесі навчання географії в умовах сучасної вітчизняної загальносвітньої школи.

Підвищення ефективності навчання географії в загальноосвітні навчальних закладах $\epsilon$ прямо пропорційним рівневі професійної компетентності та вмотивованості вчителя. Від нього залежить побудова процесу навчання на технологічній основі з урахуванням ідей гуманізації навчання та гуманітаризації географічної освіти. Значною мірою від діяльності вчителя залежить побудова навчального процесу на засадах особистісно зорієнтованого, компетентнісного, діяльнісного та краєзнавчого підходів, згідно з положеннями державних освітніх стандартів. Тому виникає необхідність у реалізації нової моделі навчання, де визначена нова місія вчителя географії.

Сучасний учитель географії має бути адаптованим до змінних умов інформаційного суспільства та вміти використовувати позитивні переваги навчального середовища. Тому його пріоритетом $\epsilon$ компетентність у різних аспектах педагогічної роботи, а саме: організаційно-діяльнісному, дидактичному та методичному.

Стосовно організації своєї педагогічної діяльності вчитель географії повинен спиратися на засади курикулуму, коли основні освітні документи розглядаються як відкрита система і використовуються в тісному їх взаємозв'язку. Нині триває процес аналізу 
державних стандартів освіти, та розробляються індикатори їх якості. Окрім цього, оновлюються та фундаменталізуються навчальні програми. Накопичені географічною та педагогічною науками значні обсяги нового матеріалу, розглядаються через призму якості географічної освіти та закладається в основу найновіших освітніх технологій і стратегій. Відповідно до принципу системного підходу в географічній освіті в рамках загальноосвітньої школи в діалектичній взаємозалежності мають функціонувати такі документи:

- Концепція географічної освіти.

- Географічна компонента Державних освітніх стандартів.

- Навчальні програми географічних курсів загальноосвітньої школи [5; 7].

Останнім часом робилися спроби поєднання аналізованих документів, які б діяли за принципом відкритої системи. Ця ідея була втілена в Концепції географічної освіти в основній школі. Вона є рамковим документом, що визначає основні напрями розвитку шкільної географії, підходи до вивчення географії, шляхи реалізації географічних знань, умінь і компетенцій. Концепція ініціює механізми оновлення й удосконалення відповідної компоненти Державних освітніх стандартів, а вже вони системно впливають на процес створення нових навчальних програм. Програми не можуть створюватися декларативно. На їх зміст мають впливати, з одного боку, положення Концепції і Стандартів, а $з$ іншого, зворотний зв'язок з користувачами програм. Такі новації, в перспективі, роблять певний крок у бік переосмислення ролі вчителя у навчальному процесі.

Ці питання є актуальними для методики навчання географії. Адже географія - одна 3 унікальних наук, яка акумулює значні інтегративні можливості. Вивчення географії в загальноосвітній школі надає можливість, з урахуванням цієї особливості, формувати в учнів цілісну наукову картину світу й адекватний ій образ світу. Без формування адекватного образу світу людина не може адаптуватися до навколишнього середовища, світу, а без цього неможливе як біологічне виживання, так і соціальна самореалізація, самоактуалізація, формування образу «Я у світі». Поняття картини світу як системи найбільш узагальнених уявлень про навколишній світ належить до числа фундаментальних понять, які виражають специфіку людини та іï буття, взаємозв'язки зі світом, найважливіші умови іiі існування. До цього слід додати, що практично-дослідна діяльність є важливою для процесу географічного пізнання, створює умови для рефлексивного розвитку особистості $[1 ; 4 ; 5]$. Основною методичною ідеєю в діяльнісному підході є бачення учня як дослідника, здобувача. Отже, учитель має перетворитися із ретранслятора знань на порадника й організатора процесу навчання. Усе це на сучасному етапі розвитку освітньої системи України ставить перед дидактикою географії нові завдання:

- коригування мети навчання - формування особистості учнів у процесі навчання шкільних курсів географії;

- розроблення критеріїв відбору змісту шкільних курсів географії відповідно до вікових особливостей учнів і різнобічних потреб суспільства, які визначатимуть їхню успішність у майбутньому;

- визначення змісту географічних компетенцій i критеріїв оцінювання рівня предметної компетентності учнів;

- дослідження ефективності застосування різноманітних дидактичних інструментів: методів, методичних прийомів, засобів і форм організації навчання;

- розроблення навчальних технологій та організація їхнього упровадження у шкільну практику; 
- розроблення системи наскрізної діагностики навчально-пізнавальної діяльності й навчальних досягнень учнів із географії;

- організація навчально-пізнавальної діяльності учнів задля формування навичок самостійного здобуття знань;

- визначення способів діяльності, орієнтованої на набуття практичного досвіду адаптації в соціумі [3].

Такі дидактичні підходи сприяють упровадженню новітніх педагогічних ідей, навчальних технологій у шкільну практику, а також надають науковцям матеріал для нових досліджень і розроблення осучаснених науково обгрунтованих рекомендацій учителям.

Основними із них є такі:

- спрямування діяльності вчителя на реалізацію мети й завдань шкільної географії, спрямованих на всебічний розвиток учнів;

- обгрунтування принципів відбору навчального матеріалу в рамках структури географії в загальноосвітніх навчальних закладах;

- розвиток психодидактичного підгрунтя навчання географічних курсів та його спрямування у практичну діяльність учителів географії;

- підвищення рівня ефективності застосування дидактичних інструментів на уроках географії;

- розроблення програм експериментальної апробації й поширення оригінальних авторських методик і технологій навчання географії;

- застосування багатоваріантних навчально-методичних комплектів;

- розроблення методичного забезпечення для реалізації профільних курсів географії;

- удосконалення змісту й форм організації позакласної роботи з географії[3].

На сучасному етапі практика вищої географічної освіти демонструє недостатність передумов для розвитку у студентів педагогічних спеціальностей якостей, що сприяють формуванню професіоналізму вчителя географії. Це стосується насамперед недостатнього використання резервів методичної підготовки студентів. Проте результати низки наукових досліджень свідчать про те, що процес професійного становлення особистості вчителя географії може успішно здійснюватися на всіх етапах модернізації підготовки майбутніх педагогів. Цей процес можна регулювати шляхом упровадження новітніх форм й активних методів навчання, психологічного супроводу навчання студентів у педагогічному ВНЗ, розроблення й упровадження спецкурсів за вибором студентів, що сприяє розвитку їхньої креативності, професійних умінь, адекватної самооцінки, спрямованності на творчу діяльність.

Ефективна реалізація основних положень географічної освіти у вищій школі має спиратися на потреби сучасної загальноосвітньої школи. Формування географічних знань i компетентностей, що їх використовуватимуть майбутні вчителі в умовах основної школи, можлива за таких педагогічних умов:

- усвідомлення та послідовне відображення у змісті й методиці формування географічних умінь сутності педагогічної діяльності як соціально-педагогічного феномена, що характеризує взаємозв'язок загальної культури, майстерності вчителя, його особистісних i педагогічних якостей, творчого потенціалу і професійної спрямованості, усвідомлення професійної та особистісної значущості майбутньої роботи;

- поєднання у процесі підготовки рефлексивно-діяльнісного, індивідуально-творчого й гуманістичного підходів;

- мотиваційне забезпечення підготовки студентів;

Педагогіка вищої та середної школи. - 2015. - Вип. 45 
- оволодіння спеціальними мислиннєвими, логічними операціями як передумовами педагогічної діяльності, що забезпечує іiї найбільшу методичну ефективність;

- надання можливостей для якнайповнішого порівняння й оцінювання професійно важливих якостей, умінь, формування об'єктивного оцінного ставлення до себе;

- залучення студентів до географічних досліджень, постановка у процесі підготовки суб'єктивно орієнтованих завдань 3 концентрацією уваги на виконанні діяльності та інформації, що обслуговує їі;

- стимулювання інтелектуальної активності та самостійності студентів;

- створення методичних рекомендацій, які включали б мотиваційний, моральнопсихологічний і змістово-операційний аспекти [5].

Сучасні дослідження в галузі педагогіки сформували новий погляд на проблеми методичної підготовки майбутніх учителів і надали змогу розглядати іiі, по-перше, як один із етапів неперервної педагогічної освіти, що здійснюється під час навчання студентів у вищих педагогічних навчальних закладах та забезпечує єдність і цілісність усіх компонентів змісту і процесу методичної підготовки вчителів географії.

Головною метою неперервної географічної освіти є сприяння формуванню високого освітньо-кваліфікаційного рівня, професійної зрілості та компетентності педагогічних кадрів, які працюють у галузі загальної шкільної освіти.

Післядипломна освіта вчителів географії має здійснюватися перманентно, упродовж усього періоду їхньої педагогічної діяльності. Таким чином буде реалізовуватися принцип «навчання протягом усього життя». Підвищення кваліфікації вчителів варто зреалізовувати на основі інноваційних методів і надання додаткової спеціалізації педагогічним працівникам. Оптимізація цього різновиду географічної освіти здійснюється на основі науковометодичного супроводу модернізації освітньої діяльності та залучення практичних педагогів до науково-дослідної робота [5].

Ураховуючи сказане вище, зазначимо, що домінувальними якостями, що характеризують рівень модернізації методичної підготовки майбутнього вчителя географії $\epsilon$ його інтелект, успішність, пізнавальна активність, дисциплінованість, організованість. На основі цього формуються самостійність, ініціативність і здатність до наукової роботи. На етапі готовності до педагогічної діяльності його мають характеризувати успішність і творча активність, на професійному рівні- організованість, пізнавальна активність й конструктивізм.

Сучасного вчителя географії в загальноосвітній школі слід розглядати як педагога здатного до вияву педагогічної майстерності, з одного боку, та до самоосвіти - 3 іншого. Він $\epsilon$ організатором навчального процесу географії, його інтенсифікатором, тому науковцями Інституту педагогіки НАПН України розробляється механізм упровадження інституту педагогічного наставництва зі значним потенціалом можливостей для стимулювання i підвищення мотивації професійного розвитку вчителів через забезпечення неперервності педагогічної освіти на основі національної специфіки та досвіду набутого в Україні. Зазначені вище положення вказують на те, що нині в навчальному середовищі потрібен учитель, який повинен шукати та застосовувати новітні освітні технології, спрямовані на формування вміння пошуку, збору та аналізу інформації; здійснення дослідницької діяльності учнями та розв’язання проблем практичного характеру.

\section{Література}

1. Бабанский Ю. К. Оптимизация процесса обучения: Общедидактический аспект/ Ю. К. Бабанский. - Москва : Педагогика, 1977. - 96 с. 2. Бондар В. І. Дидактика: [навч. 
посіб.] / В. І. Бондар. - Київ : Либідь, 2005. - 264 с. 3. Дидактика географії: [монографія] / В. М. Самойленко, О.М. Топузов, Л. П. Вішнікіна, О. Ф. Надтока, І. О. Діброва. - Київ : Педагогічна думка, 2014. - 586 с. 4. Гершунский Б. С. Концепция самореализации личности в системе обоснования ценностей и целей образования / Б. С. Гершунский // Педагогика. 2003. - № 10. - С. 3-7. 5. Концепція географічної освіти в основній школі: проект/ Інститут педагогіки НАПН України / за заг. ред. О. М. Топузов, О. Ф. Надтока, Л. П. Вішнікіна, А. С. Доброскок та ін. - Київ : Педагогічна думка, 2014. - 30 с. 6. Кремень В. Г. Філософія національної ідеї: Людина. Освіта. Соціум / В. Г. Кремень. - Київ : Грамота, 2010. - 576 с. 7. Надтока О. Ф. Особистісно зорієнтований підручник з географії як одна з вимог сучасної освіти / О. Ф. Надтока // Географія та економіка в сучасній школі. - Київ : Педагогічна преса, 2012. - № 1. - С. 6-11. 8. Топузов О. М. Педагогічна прогностика: теоретико-методична основа прогнозування розвитку педагогічних наук і педагогічної практики / О. М. Топузов // Рідна школа. - 2014. - № 7. - С. 32-36.

Інеса Хмеляр

\section{ДОСЛІДНИЦЬКИЙ ПІДХІД ДО ОРГАНІЗАЦІї НАВЧАЛЬНО-ВИХОВНОГО ПРОЦЕСУ В КОЛЕДЖІ - УМОВА САМОРОЗВИТКУ СТУДЕНТА}

Хмеляр І. М. Дослідницький підхід до організації навчально-виховного процесу в коледжі - умова саморозвитку студента.

У статті розкрито та науково обгрунтовано застосування в навчально-виховному процесі медичних коледжів дослідницького підходу як однієї з умов саморозвитку студента. Установлено, що дослідницький підхід до навчальної діяльності студента сприяє вихованню особистості, здатної до самореалізації, професійного зростання в умовах реформування сучасного суспільства.

Ключеві слова: саморозвиток, дослідницький підхід, інноваційний процес, самореалізація.

Хмеляр И. М. Исследовательский подход к организации учебно-воспитательного процесса в колледже - условие саморазвития студента.

В статье раскрыто и научно обосновано применение в учебно-воспитательном процессе медицинских колледжей исследовательского подхода как одного из условий саморазвития студента. Установлено, что исследовательский подход к учебной деятельности студента способствует воспитанию личности, способной к самореализации, профессионального роста в условиях реформирования современного общества.

Ключевые слова: саморазвитие, исследовательский подход, инновационный процесс, самореализация.

Hmelyar I. M. Research approach to the organization of educational process in college as a condition for student's self-development.

The adaptation of research approach as one of the conditions for student's self-development in the educational process of medical colleges is revealed and proved. It is determined that the research approach in learning activity contributes to character education for self-actualization and professional growth in the conditions of reforming of modern society.

Key words: self-development, research approach, innovative process, self-actualization.

Педагогіка вищої та середної школи. - 2015. - Вип. 45 